DOI: $10.1387 / \mathrm{hc} .17595$

\title{
LA CLAVE CORTESI. LA POLÍTICA VATICANA EN LA REPÚBLICA ARGENTINA (1926-1936)
}

\section{CORTESI CONNECTION. VATICAN POLICY IN THE ARGENTINE REPUBLIC (1926-1936)}

\author{
José Ramón Rodríguez-Lago \\ Universidad de Vigo (España) \\ ORCID: 0000-0003-4235-8863
}

Recibido el 26-4-2016 y aceptado el 6-9-2016

Resumen: El gobierno de Filippo Cortesi como nuncio en Buenos Aires durante una década decisiva permite adentrarse en la visión que la curia pontificia tuvo del desarrollo de los acontecimientos en la Argentina de entreguerras y la aplicación de las diversas estrategias adoptadas en defensa de sus intereses. La documentación generada por la nunciatura y la Secretaría de Estado del Vaticano evidencia como las dinámicas internas de la república platense se vieron condicionadas por el complejo juego dialéctico atravesado por una corporación cada vez más centralizada y global.

La política de Ralliement propiciada previamente por Benedicto XV y el obispo De Andrea, se vio reemplazada por la revolución conservadora de Pío XI, Pietro Gasparri y Vlodimir Ledochowsky, que apostaron por restaurar una alianza con las oligarquías en un contexto de crisis del liberalismo y emergencia de Estados autoritarios. El golpe del general Uriburu en septiembre de $1930 \mathrm{y} \mathrm{el}$ posterior gobierno del general Justo contaron con el apoyo del nuncio y su mayor aliado, Santiago Luis Copello, pronto designado arzobispo y encumbrado como cardenal. El Congreso Eucarístico Internacional celebrado en 1934 en Buenos Aires certificaría ante el cardenal Pacelli el éxito de aquella estrategia.

Palabras clave: Iglesia, Argentina, Vaticano, Agustín Pedro Justo, Congreso Eucarístico Internacional.

Abstract: The government of Filippo Cortesi as Nuncio in Buenos Aires for ten years enables us to enter in the vision of the Papal curia about the development of events in Argentina during the interwar period and the implementa- 
tion of various ecclesiastical strategies adopted in pursuit of their interests. The analysis of the documentation generated by the Nunciature and by the Vatican Secretary of State brings to light how the internal dynamics of the Church in the Platense Republic were conditioned by a complex and dialectical interplay that it was experienced for a corporation increasingly global and centralized.

The Ralliement policy, previously favored by Benedict XVI and by Bishop De Andrea, was replaced by the conservative revolution of Pius XI, Pietro Gasparri and Vlodimir Ledochowski, who supported the restoration of an alliance with the oligarchies in a context of liberalism's crisis, and emergence of authoritarian states. The coup of General Uriburu in September 1930 and the subsequent government of General Justo had been supported by the nuncio and his greatest ally, Santiago Copello, who was soon appointed as archbishop and extolled as cardinal. The International Eucharistic Congress held in 1934 in Buenos Aires would certify the success of that strategy to cardinal Pacelli.

Keywords: Church, Argentina, Vatican, Agustín Pedro Justo, International Eucharistic Congress. 
La elección en marzo de 2013 de Jorge Mario Bergoglio como pontífice, tras la inesperada renuncia al papado de Benedicto XVI, desató una espiral mediática de comentarios en torno a la influencia emergente del continente americano en los intereses católicos. La designación del cardenal argentino como primado de la Iglesia romana y jefe del Estado Vaticano rubricaba la trayectoria de la corporación eclesial en las repúblicas americanas durante el pasado siglo. Si los católicos de los Estados Unidos fueron tras la primera guerra mundial la principal fuente de financiación e inspiración de nuevas prácticas pastorales y organizativas ${ }^{1}$, la república platense sirvió de campo propicio para la aplicación de las políticas vaticanas extendidas al sur del continente.

El rol desempeñado por la Iglesia católica en Argentina durante el período de entreguerras ha propiciado en los últimos años un enriquecedor debate historiográfico. La obra de Loris Zanatta ha destacado el papel jugado por las instituciones pontificias en la esfera política y militar ${ }^{2}$, y los trabajos de Miranda Lida y Diego Mauro han ofrecido un análisis de la evolución «ad intra» del contexto eclesial desde los años precedentes, abordando desde una perspectiva social los procesos de cambio impulsados por los católicos ${ }^{3}$. Lejos de resultar antitéticos, estos valiosos estudios han aportado un bagaje complementario del intenso panorama de transformaciones acometidas en la República por las instituciones eclesiásticas en aquellas décadas.

No siempre resultó fácil conciliar los procesos emergentes en América con las exigencias derivadas del modelo centralizador impuesto por la curia romana. La dialéctica «nacionalización versus romanización» debe verse necesariamente arropada por un análisis que se adentre en los conflictos generados por los distintos planteamientos doctrinales y las diversas estrategias aplicadas durante los pontificados de Benedicto XV y Pío XI. Los ecos que sus políticas, sus promotores y sus detractores suscitaron en Argentina merecen mayor detenimiento para la comprensión de una realidad eclesiástica siempre compleja y dialéctica.

El análisis de una parte de la documentación generada por el siciliano Filippo Cortesi, que ejerció como nuncio en Buenos Aires entre octubre de 1926 y junio de 1936, y las memorias producidas por la sección de

1 DOLAN, 2002.

2 ZANATTA, 1996 y 1999; DI ESTEFANO y ZANATTA, 2009.

${ }^{3}$ MIRANDA y MAURO (coord.) 2009; MIRANDA, 2009, 345-370; 2010, 809-836; 2012, 401-422; MAURO, 2015, 181-205; 2014,: 235-262. 
Asuntos Eclesiásticos Extraordinarios de la Secretaría de Estado del Vaticano en ese mismo período, permiten conocer con detalle la imagen que la curia romana tuvo de esos acontecimientos. A los informes exhaustivos elaborados por el nuncio y las respuestas o silencios siempre significativos de la Secretaría de Estado, se suman los allegados por otras instancias del episcopado, del clero o de los seglares que contaron con peso decisivo en aquellos días. Una documentación que muestra las disputas y agrias polémicas surgidas entre los católicos de Argentina, enzarzados en una lucha entre diferentes modelos eclesiales ${ }^{4}$.

En marzo de 1930, Federico Tedeschini, nuncio en Madrid, envió a su amigo y antiguo compañero en la Secretaría de Estado, Eugenio Pacelli, sólo desde hacía unas semanas al frente de la institución más poderosa de la curia vaticana, la carta que un sacerdote español destinado en Argentina había enviado al cardenal arzobispo de Granada, Vicente Casanova y Marzol. La misiva reflejaba una imagen alarmante de la realidad del catolicismo en la próspera república y su populosa capital porteña ${ }^{5}$. Los testimonios recogidos en esas fechas por la Secretaría de Estado respecto a la situación de la Iglesia católica en Argentina evidenciaban intensos conflictos, no sólo entre la cúpula eclesiástica y las instituciones estatales, sino en el seno del mismo clero, reacio a someterse a las disposiciones dictadas por la curia romana. Como si se tratase de un prodigioso milagro, en octubre de 1934, mientras Eugenio Pacelli era aclamado como legado pontificio por las multitudes congregadas durante el Congreso Eucarístico Internacional; el arzobispo de Toledo, Isidro Gomá, recién llegado desde la «madre patria», comprobaba asombrado como la república aus-

${ }^{4}$ El autor consultó entre marzo y junio de 2014 los fondos documentales del Archivo Secreto Vaticano (ASV) relativos a la nunciatura de Argentina (ANA), la de Madrid (ANM), los de la sección de Asuntos Eclesiásticos Extraordinarios de la Secretaría de Estado del Vaticano (AA.EE.SS.) y los de Archivo Central de la Compañía de Jesús en Roma (ARSI); y entre abril y junio de 2015 los fondos documentales de la National Catholic of Welfare Conference (NCWC), en la Catholic University of America (CUA), Washington DC.

5 «Temo que el primer cisma que tenga que lamentar la Iglesia sea el argentino y si no se produjo ya, fue debido a la diplomacia y tacto de Roma y a la conveniencia argentina de no perder el derecho de presentación de obispos... Hay aquí un patriotismo tan exagerado y tan sui generis y un concepto y culto de la independencia argentina contagiado a curas y a obispos, que es peligrosísimo. Aquí un cura, primero es argentino y después sacerdote». Francisco Ruiz Pérez, párroco de Roldán, Santa Fe, Argentina, al cardenal arzobispo de Granada, España (12/01/1930). Enviada a la Secretaría de Estado por Federico Tedeschini, nuncio en Madrid (4/03/1930). AA.EE.SS. Argentina, Fascículo 66: 3-5. 
tral se había convertido en modelo del catolicismo triunfante. Cortesi expresaba entonces su satisfacción por los sueños cumplidos y se atrevía a augurar un futuro próspero para toda la Iglesia católica en Latinoamérica ${ }^{6}$. Analizar las circunstancias que esbozaron esa imagen triunfal requiere poner en relación los procesos internos vividos en Argentina y la intervención emergente de la corporación transnacional a través de sus más cualificados representantes.

\section{La Iglesia católica en Argentina antes de Cortesi. De Benedicto XV a Pío XI}

Filippo Cortesi tenía 50 años cuando el 19 de octubre de 1926 tomo posesión de su cargo como nuevo representante pontificio en la nunciatura de Buenos Aires. Su gestión de la diplomacia vaticana en la principal metrópoli de Latinoamérica transformaría la relación entre el Estado, la Iglesia y la sociedad argentina, pero, habida cuenta de los conflictos previos, sus primeros pasos resultaron sigilosos. Siguiendo las orientaciones otorgadas por la Secretaría de Estado, cuatro eran los objetivos de su gobierno: establecer unas relaciones más estrechas con las altas instituciones del Estado; imponer un férreo control sobre un clero secular caracterizado por la indisciplina; impulsar la actuación de las congregaciones religiosas bajo los parámetros acuñados en Roma; y sujetar a las organizaciones seglares surgidas en los años anteriores a las directrices de la jerarquía pontificia.

La Iglesia argentina llevaba años envuelta en los conflictos desatados tras la coronación papal de Pío XI. Durante el pontificado de Benedicto XV, el gobierno de Hipólito Yrigoyen había contado con el beneplácito de una acción eclesial más proclive al reencuentro con los gobiernos salidos de las urnas ${ }^{7}$. La larga enfermedad del anciano arzobispo metropolitano Mariano Antonio Espinosa y la mediación del nuncio Alberto Vasallo de Torregrossa, llegado desde Roma en mayo de 1916, había poten-

${ }^{6}$ «Un signo y un auspicio feliz de la misión providencial que por el bien del mundo podrá desarrollar América latina con una población de más de 80 millones de habitantes, rica de inmensas energías y de incalculables recursos materiales». Cortesi a Secretaría de Estado sobre la celebración del Congreso Eucarístico de Buenos Aires (16/11/1934). ASV, ANA, Caja 121, Fascículo 592: 80-82.

7 POLLARD, 2014, 2005 y 1999. 
ciado entonces la figura de un joven obispo auxiliar que parecía llamado a liderar la Iglesia argentina. Miguel de Andrea, formado en el Colegio Pío Latinoamericano y en la Universidad Gregoriana de Roma, era fiel reflejo de la preocupación social-católica y la estrategia posibilista inspirada por el pontificado leonino ${ }^{8}$. En 1904 ejercía ya como secretario personal del arzobispo Espinosa y desde 1912 se hizo cargo de la dirección de los Círculos Obreros Católicos. Máximo aliado de De Andrea en aquellos años fue el sacerdote Gustavo Franceschi, secretario de la Liga Social Argentina desde 1911. En 1918 ambos fundaron la Unión Popular Católica Argentina (UPCA), que al año siguiente organizó el primer Congreso $\mathrm{Ca}$ tólico-Social de América Latina y promovió una Gran Colecta Nacional para recaudar fondos para la construcción de obras sociales. Como rector de la primera Universidad Católica en Argentina, De Andrea también promovió un renacer intelectual del catolicismo en contacto con la modernidad. Significativamente, el éxito de aquellas iniciativas fue observado con inusitado interés en España, donde el diario El Debate, dirigido por Ángel Herrera, se presentó como adalid de la aplicación de sus valiosas enseñanzas $^{9}$.

En enero de 1922 Pío XI demostró muy pronto un cambio de tendencia, que no sólo se evidenció en el reforzamiento de la soberanía pontificia en base a un concepto hierocrático, sino en la política de nuevas designaciones pontificias, en España y en Argentina. Aquille Ratti y su poderoso Secretario de Estado, Pietro Gasparri, evidenciaron su oposición a la diplomacia conciliadora del anterior pontífice. La actividad incesante de De Andrea se había ganado la admiración de algunos sectores populares, pero había generado al tiempo la animadversión de una buena parte de las oligarquías conservadoras, que, en las repúblicas americanas o en el reino de España, se sentían entonces atemorizadas por el arrebatador empuje de los movimientos populares, fuesen o no

${ }^{8}$ Sobre su biografía y su trascendental trayectoria en la Iglesia argentina para la primera mitad del siglo xx véase MIRANDA, 2013.

${ }^{2}$ «En seis naciones hispanoamericanas se ha hecho la Gran Campaña y, al final, en condiciones bien difíciles, han obtenido sin embargo resultados prácticos grandiosos, superiores a cualquier esperanza. ¿Por qué -se preguntan los organizadores-esta Gran Campaña no se puede, no se debe intentar también en España; la única nación europea integramente católica y que se ha mantenido al margen de la conflagración mundial?». Federico Tedeschini, nuncio en Madrid, a Secretaría de Estado sobre la Gran Campaña Social (20 de marzo de 1922). AA.EE.SS. Spagna IV, Fascículo 32: 44 a 51. 
católicos ${ }^{10}$. El obispo auxiliar de Buenos Aires llegó a Madrid en marzo, sólo unos días antes de la suspensión definitiva de la Gran Campaña por el episcopado español ${ }^{11}$; pero cuando retornó a Buenos Aires, pudo confirmar que los vientos de la curia vaticana soplaban en dirección opuesta al rumbo marcado en los años previos.

El 8 de abril de 1923, mientras De Andrea iniciaba su travesía de regreso a Argentina, fallecía el arzobispo Espinosa. A los conflictos abiertos previamente por la resistencia gubernamental para la erección de nuevas diócesis, se sumaría ahora la tensión por la provisión de un nuevo arzobispo para la capital porteña. La presentación de los candidatos a ocupar la sede primada de la Iglesia argentina alimentó una agria disputa entre un gobierno que blandía el privilegio de presentación otorgado por el régimen de patronato, y las instancias pontificias, que deseaban tener la última palabra en aquella decisiva designación. El gobierno y el senado argentino defendieron públicamente la promoción de Miguel de Andrea, que a sus 46 años llevaba ya un tiempo ejerciendo como obispo auxiliar y contaba con la estima del partido en el gobierno; pero en julio la curia vaticana dispuso que Alberto Vasallo, aliado y amigo de De Andrea abandonase la nunciatura, y la Universidad Católica fuese disuelta. El 9 de octubre, tres días antes de que Marcelo Torcuato de Alvear accediese a la presidencia de la República, un nuevo nuncio, Giovanni Beda Cardinale tomó posesión de la sede de la nunciatura.

A través de Beda, Pío XI y Gasparri se mostraron férreos partidarios de la promoción de Juan Agustín Boneo, que a sus 78 años, y tras servir 25 años a la causa eclesial como obispo de la diócesis de Santa Fe, se había convertido en significado paladín de los valores tradicionales frente al empuje de la modernidad; pero la candidatura de Boneo, conocido por su arrebatada defensa de las tesis más ultramontanas, fue rechazada ta-

10 «El Rey ha encargado una investigación a su encargado de negocios en Argentina y el encargado ha respondido... El único resultado práctico de la colecta argentina es el enorme malestar que ha crecido entre los ricos y los pobres; unos porque han dado y otros porque no han recibido, y mucha decepción en todo el pueblo contra los promotores de la colecta». Tedeschini a Secretaría de Estado (22/03/1922). AA.EE.SS. Spagna IV, Fascículo 32: 61-64.

11 «Madrid no ha dejado de manifestarle su gratitud y su admiración... Tras Monseñor De Andrea está Argentina; la Argentina a la que el Rey ha querido dar una satisfacción por las ofensas a la persona del obispo, y para prevenir cualquier recrudecimiento de las relaciones ibero-americanas que la madre patria insiste ahora en fomentar». Tedeschini a Secretaría de Estado (12/04/1922). AA.EE.SS. Spagna IV, Fascículo 32: 75-76. 
jantemente por el gobierno y la Corte Suprema. Las negociaciones para el nombramiento del nuevo arzobispo adquirieron entonces calado internacional. La Santa Sede envío como delegado pontificio en Latinoamérica al cardenal español Juan Bautista Benlloch ${ }^{12}$, que visitó Argentina en septiembre de 1923, mientras llegaban de España los ecos del golpe militar de Miguel Primo de Rivera ${ }^{13}$. Dos meses más tarde, la audiencia de Alfonso XIII ante Pío XI y la alusión en su discurso a las cuestiones eclesiásticas de la América hispana produjo enorme malestar no sólo entre las autoridades de la república, sino entre una buena parte del clero argentino, que reivindicaba su autonomía frente a las intromisiones extranjeras ${ }^{14}$.

Tras sucesivas negociaciones, el ministro de Asuntos Exteriores y Culto, Ángel Gallardo, propuso ceder en la candidatura gubernamental de De Andrea, a cambio de la retirada del nuncio Beda y la sustitución del candidato Boneo por el superior de los franciscanos José María Bottaro, que parecía aceptable para ambas partes. En agosto de 1925, Beda abandonó Buenos Aires; en octubre, De Andrea presentó su renuncia al arzobispado. Casi un año más tarde, en septiembre de 1926, Bottaro, de 66 años, fue designado nuevo arzobispo de Buenos Aires. La tregua declarada entre el gobierno argentino y las autoridades pontificias no supuso el final de la batalla por tomar las riendas del futuro. Para la Secretaría de Estado y para Pío XI la oposición de la Unión Cívica Radical a los designios del pontífice tenía claros cómplices eclesiales. De Andrea, Franceschi y sus aliados seglares de la Unión Popular Católica Argentina se habían enfrentado a las disposiciones papales e impedían el progreso de los postulados bendecidos por el nuevo pontífice ${ }^{15}$. Como opositores eran to-

12 DOMÍNGUEZ, 2013.

13 «Hablando conmigo (que he creído oportuno informarlo de cuanto está pasando con la provisión de la sede arzobispal y el estado actual de la cuestión) me dijo que Mons. De Andrea, a causa de la campaña de Madrid, había producido en el episcopado español una impresión poco favorable». Giovanni Beda, nuncio en Argentina, a Secretaría de Estado (1/10/1923). AA.EE.SS. Spagna IV, Fascículo 60: 66-68.

${ }_{14}$ «El gobierno de Argentina que no había sido advertido de tal paso por el Soberano... lo considera un acto de alta tutela que el Rey ha ejercido por encima de las repúblicas sudamericanas». De Giovanni Beda a Tedeschini sobre el conflicto suscitado en Argentina por el discurso del rey Alfonso XIII ante el Papa Pío XI (noviembre de 1923). AAEESS. Spagna IV, fascículo 60: página 72.

15 «Durante el conflicto por la provisión de la archidiócesis de Buenos Aires, Monseñor Francheschi fue siempre considerado el brazo derecho de Monseñor Andrea... Su conducta era del todo escandalosa». Informe de Secretaría de Estado sobre denuncias presentadas contra Gustavo Franceschi (24/03/1933). AAEESS. Argentina, Fascículo 73: 8-18. 
davía demasiado fuertes como para ser derrotados, pero el Vaticano confiaría una vez más en un enemigo implacable: el paso del tiempo.

\section{Derribar el pasado; diseñar el futuro. Cortesi y el proceso de destrucción creativa}

Fue tras este periplo de desencuentros entre las autoridades gubernamentales y las propuestas de Pío XI cuando Filippo Cortesi llegó a Buenos Aires. Desarrollar su misión requería desmontar algunas de los entramados institucionales que pervivían del pontificado de Della Chiesa y poner los cimientos para diseñar un modelo eclesial proclive a las nuevas directrices. Contaba con su experiencia previa como nuncio en Caracas, donde desde 1921 había alcanzado un régimen de concordia con el General Juan Vicente Gómez Chacón, que con la ayuda del ejército controlaba férreamente la república venezolana. Su historial diplomático demostraba que el estamento militar podía convertirse en aliado de los intereses eclesiásticos siempre que supiesen cultivarse las relaciones adecuadas. La reforma del reglamento del servicio castrense aprobada en julio de 1923, con el católico Agustín Pedro Justo al frente del ministerio de la guerra, posibilitaba explorar esa vía; pero una vez más, convenía debilitar las posiciones tomadas por los representantes de la «vieja» Iglesia argentina entre las élites militares. El protagonismo de De Andrea y Franceschi entre los oficiales de la marina, se vería sustituido pronto por el rol ejercido por los nuevos favoritos eclesiales. En junio de 1928 el recién nombrado nuevo obispo auxiliar de Buenos Aires, Santiago Luis Copello, fue designado también vicario general del ejército. Él sería el encargado de cumplir «manu militari» los designios del nuncio.

Al margen de los conflictos suscitados en materia política, el aspecto que suscitaba mayores preocupaciones entre la curia romana era la tendencia manifiesta a la indisciplina de una buena parte de los sacerdotes. La obra de Loris Zanatta ha analizado la influencia del clero castrense en el proceso de confesionalización del ejército argentino; resulta significativo constatar a su vez el proceso de «militarización» del clero argentino en esos mismos años. La extendida insubordinación respecto a los dictados de la jerarquía pontificia resultaba intolerable tras la aprobación del Código de Derecho Canónico Universal y era urgente tomar medidas oportunas para someter al irresoluto clero diocesano. El protagonismo cobrado en los años futuros por los dirigentes eclesiásticos que habían demostrado su valía en el cuerpo castrense tendría mucho que ver con la obsesión por asegurar la 
sumisión del cuerpo eclesial a los dictados jerárquicos. La designación de tres nuevos obispos en las diócesis de Córdoba, Paraná y Santiago del Estero supuso no sólo una oportunidad para amoldar al episcopado a las nuevas orientaciones vaticanas, sino también para reivindicar la soberanía moral y religiosa de la doctrina pontificia sobre cualquier otra autoridad. En octubre de 1927 coincidiendo con la consagración de los nuevos obispos, el episcopado argentino publicó una Carta Pastoral Colectiva titulada «La verdadera Iglesia de Jesucristo y el Primado del Romano Pontífice» ${ }^{16}$. La exaltación de la primacía pontificia cobraba una importancia singular. No podía existir duda alguna: un verdadero católico debía asumir plenamente los designios de la voluntad papal. La exaltación de las tesis de la cruzada en el diario El Pueblo, que hasta ese momento había mantenido una postura más conciliadora con la modernidad, confirmaba el avance en la redacción de las posiciones del nuncio ${ }^{17}$.

Con un clero secular escaso y carente de confianza entre las autoridades pontificias, las congregaciones religiosas se habían convertido en punta de lanza del proceso de romanización. Los misioneros y los sacerdotes llegados de Europa, italianos y españoles prioritariamente, encontraron acomodo en el destino americano, pero muchos se americanizaban en exceso. Las tradiciones por las que Roma seguía velando exigían de un mayor control disciplinar por parte de los obispos o de cada uno de los superiores. Benedicto XV, el pontífice de las misiones, había favorecido la labor ejercida por los salesianos que en julio de 1924 celebraron en Buenos Aires su IX Congreso Internacional, el segundo celebrado en Argentina ${ }^{18}$; pero al éxito alcanzado por los salesianos, con una larga tradición en la atención de los barrios populares, se sumó el trabajo de nuevas congregaciones educativas que como las de los Hermanos Maristas, llegados desde el exilio francés en 1903 y que constituyeron una provincia del Instituto religioso desde 1920, extendieron su influencia en la educación de las clases medias. Sin embargo, fueron los jesuitas los que por entonces

${ }^{16}$ Pastoral colectiva del episcopado argentino La verdadera Iglesia de Jesucristo y el Primado del Romano Pontífice (16/10/1927). ASV, ANA, Caja 113, fascículo 561: 152-164.

17 MIRANDA, 2008.

18 «El brillante éxito y los resultados prácticos y sorprendentes de los ocho Congresos Internacionales Salesianos realizados en diversas naciones... Los magníficos frutos alcanzados en el Congreso de 1900 celebrado en esta misma capital, nos hacen esperar iguales resultados y mayores si así cabe». Carta del presidente de la Junta Ejecutiva del IX Congreso Internacional de cooperadores salesianos (julio de 1924). ASV, ANM, Caja 884: 3-4. 
exaltaron al máximo el sagrado binomio de jerarquía y disciplina que la curia vaticana ansiaba poner en práctica ${ }^{19}$.

Bajo el gobierno del Prepósito General Wlodimir Ledochowski desde febrero de 1915, la congregación ignaciana se convirtió en baluarte del tradicionalismo frente a cualquier atisbo de modernidad. Si en 1908 la publicación en Buenos Aires de la revista Estudios marcó un hito en la influencia jesuítica en Latinoamérica, diez años más tarde se constituyó la Provincia Argentino-Chilena, que bajo los auspicios del catalán José Llusa incluía las misiones de Argentina, Chile, Uruguay y Paraguay, por primera vez independientes de los designios de la tradicional provincia de Aragón. Desde 1924, otro catalán, Ramón Lloverola Cortadellas, ejerció como provincial de un territorio que en abril de 1929 contaba con 507 jesuitas; 153 residían en Buenos Aires y 116 en Córdoba ${ }^{20}$. Llegados en su mayor parte desde España y convertidos en herramienta del nuncio para aplicar las tesis romanas, los jesuitas propiciaron a su vez un relato histórico en el que la hermandad hispánica se veía forjada por la tradición católica ${ }^{21}$.

Principal centro de ocupación del nuncio en esos años será la implantación progresiva de una Acción Católica que, sujeta a los códigos jerárquicos y confesionales establecidos por Pío XI, se distanciase del movimiento católico que se había ido desarrollando en Argentina hasta esa fecha, juzgado como altamente nocivo para los intereses eclesiales ${ }^{22}$. Im-

19 «Hay también muchísimo bueno. Los jesuitas por ejemplo, que son iguales en todo el mundo; carmelitas, agustinos, dominicos, franciscanos y capuchinos, que tienen parroquias y trabajan dando gloria a Dios, aunque como órdenes religiosas, en estas latitudes no son de la observancia austera de nuestros Capuchinos del triunfo. Los misioneros del Corazón de María, españoles, bastante extendidos y de los de más eficaz trabajo. Y sobre todo, las congregaciones de mujeres, atendiendo hospitales y colegios (como nuestras Hermanas de la Caridad, las Hijas de San Vicente), de esto sí está sembrada toda la República, y yo no dudaría en afirmar que el beneficio principal de la religión vive de ellas». Francisco Ruiz Pérez, párroco de Roldán, Santa Fe, Argentina, al cardenal arzobispo de Granada España (12/01/1930). Enviada por el nuncio de España la Secretaría de Estado (4/03/1930). AAEESS, Argentina, Fascículo 66: 3-5.

${ }^{20}$ Estadística para el mes de abril de 1929 recogida en Catalogus Provinciae Argentino-Chilensis. S. J. (Argentina, Chile, Uruguay y Paraguay), 1929.

21 GONZÁLEZ, 2007, pp. 599-642.

22 «La reforma de la Unión Popular Católica Argentina. Es sabido por la Santa Sede que esta institución, implantada en 1918 con carácter nacional y fastuosas apariencias, no contó desde el principio con la opinión favorable de una buena parte del clero y del laicado. En vez de unir y disciplinar las fuerzas católicas del país, corrió el riesgo de disolverlas». Cortesi a Secretaría de Estado (24/12/1928). AAEESS. Argentina, Fascículo 66: 34-36. 
plantar ese nuevo modelo de acción eclesial requería de un clero forjado para la causa, que, a ojos del nuncio, brillaba por su ausencia ${ }^{23}$. Una vez más, clérigos nacidos en España como el vasco Zacarías de Vizcarra o el catalán Gabriel Palau resultaron decisivos para aplicar las nuevas orientaciones. Como era previsible, la constitución de la Acción Católica Argentina entraba a su vez en colisión con las voluntades de los dirigentes y el patrimonio relacional y material atesorado en los años precedentes por la UPCA. Un proceso de destrucción creativa que debía acometerse con la suficiente cautela como para evitar un enfrentamiento directo que podría resultar fatal para los intereses de la Iglesia. El primer paso en el reforzamiento de la estrategia del nuncio fue favorecer el grupo de jóvenes universitarios que desde 1922 había organizado los denominados Cursos de Cultura Católica, dirigidos por el prestigioso jurista Tomás Darío Casares. En 1928 la publicación del primer número del semanario Criterio supuso la consagración pública de sus partidarios, que pronto exhibieron un discurso muy crítico con el gobierno de Yrigoyen y el régimen parlamentario. Desde noviembre de 1929 los contenidos de la revista se vieron sometidos a los dictados de la jerarquía; resultaba imprescindible distanciarse de aventuras políticas como las iniciadas por el Partido Popular Argentino fundado en 1927 por José Pagés, que, como había ocurrido años antes con el Partito Popolare fundado en Italia por Luigi Sturzo, o el Partido Social Popular liderado en España por Severino Aznar, se vería abandonado a su suerte ${ }^{24}$.

La gerontocracia instalada en las cúpulas eclesiásticas y gubernamentales facilitó además el proceso de cambio supervisado desde la nunciatura. El arzobispo Bottaro se resintió muy pronto de su edad y su enfermedad en un proceso similar al vivido por el presidente Yrigoyen. La debilidad de ambos dificultaba tomar decisiones en un período de intensa

23 «La dificultad principal consiste en la ausencia de personas preparadas y activas que puedan asumir el encargo de coordinar y dirigir la Acción Católica según las normas de la Santa Sede... Enviar a Roma sacerdotes bien escogidos... podrían ser recibidos en el Colegio Latino Americano o en otro Instituto... Ya he solicitado también la venida de un Padre Jesuita relevante en esta materia para dictar en el próximo agosto un curso de conferencias a los jóvenes de la AC en el Centro de Cultura Católica de Buenos Aires». Cortesi a Secretaría de Estado (19/05/1929). AAEESS. Argentina, Fascículo 66: 39-40.

${ }^{24}$ La relación epistolar mantenida en los años siguientes entre Luigi Sturzo y los integrantes del Grupo de la Democracia Cristiana en España es abordada con detalle en BOTTI, 2012; para el caso argentino ver MAURO, 2014-2015. 
agitación en el frente eclesial, pero también en el económico, caracterizado por las consecuencias de la crisis de 1929, y en el político, marcado por el ascenso de regímenes autoritarios. Mientras tanto, los grandes perjudicados de la nueva política eclesial fueron todos aquellos que habían alcanzado influencia durante el pontificado de Benedicto XV. Miguel de Andrea no sólo se vería censurado para alcanzar la cúspide de la jerarquía eclesiástica, sino que observaba ahora como sus iniciativas eran denostadas por los intereses de la oligarquía conservadora. En enero de 1930 las quejas ante su antiguo amigo y aliado, Alberto Vasallo, destinado entonces como nuncio en Munich, así lo manifestaban ${ }^{25}$. En esas mismas fechas, Cortesi insistía en denunciar ante el Vaticano el comportamiento de los dirigentes de la UPCA, máximos causantes de las dificultades impuestas en la esfera gubernamental para avanzar en el proyecto de constitución de la Acción Católica ${ }^{26}$.

En junio de 1926 la movilización de las masas católicas durante el XXVIII Congreso Eucarístico Internacional celebrado en Chicago había exhibido una sobresaliente capacidad para convertir las campañas de exaltación del pontífice en una excelente plataforma de vanguardia del catolicismo. En abril de 1930 las gestiones para la organización del XXXII Congreso Eucarístico Internacional en la ciudad de Buenos Aires comenzaron a obtener los resultados ansiados. La candidatura se había presentado anteriormente, durante el Congreso Eucarístico de Ámsterdam de 1924; pero en esta ocasión, los delegados argentinos asistentes al Con-

25 «Por aquí las cosas eclesiásticas no van bien. El Exc. Arzobispo Mons. Bottaro, cada vez peor de salud y ciertamente incapacitado, no puede ocuparse de nada... La autoridad eclesiástica local no ofrece garantías porque V.E. sabe que han sido los opositores sistemáticos de la acción; al extremo de que los que pensaban como ellos secuestraban hasta documentos pontificios como el autógrafo de Benedicto XV, para no autorizar nuestra acción ... Los dos centritos, que se presentaban en estos últimos años como salvadores de la ortodoxia de la doctrina: el Centro de Cultura Católica de jóvenes varones y el de estudios religiosos de las mujeres, fenecen... Se han subdividido hasta el infinito y la mayor parte de ellos se han dado a la política contra el gobierno rabiosamente. Esto compromete ante el gobierno a los hombres de Iglesia que los han estado propiciando preferentemente». Carta confidencial de Mons. De Andrea al nuncio en Baviera, Alberto Vasallo (6/01/1930), enviada desde Múnich al nuevo Secretario de Estado, Eugenio Pacelli (14/03/1930). AAEESS. Argentina, Fascículo 66: 50-51.

${ }^{26}$ «A la conocida morosidad del gobierno... Se añade el círculo de personas eclesiásticas y laicas que ven todo con los ojos cegados hasta el fanatismo por la obra principal de Mons. De Andrea». Cortesi a Secretaría de Estado sobre las dificultades para la aprobación de los Estatutos de AC (23/01/1930). AAEESS. Argentina, Fascículo 66: página 42. 
greso celebrado en Cartago, en un Túnez bajo el dominio colonial francés, realizaron un periplo previo por Europa para garantizar el triunfo su candidatura. Tomás Rufino Cullen, antiguo ministro de Justicia e Instrucción Pública entre 1914 y 1915, y su esposa, Elina Crisal, delegada de la Tercera Orden Franciscana, establecieron los contactos pertinentes en la curia y se entrevistaron privadamente con Eugenio Pacellii ${ }^{27}$. Durante su travesía por Italia, Cullen mantuvo correspondencia con Cortesi a quien manifestaba su interés por introducir las enseñanzas del clero italiano en Argentina, la intención de invitar al Conde Della Torre o al Padre Gemelli a visitar Buenos Aires, y la admiración por la ejemplar obra realizada por Mussolini en la Italia «della conciliazione» ${ }^{28}$. El 8 de mayo de 1930 los delegados de Latinoamérica presentaron oficialmente su candidatura para celebrar el próximo Congreso en Buenos Aires patrocinando un proyecto de expansión del movimiento eucarístico por todas las diócesis del continente ${ }^{29}$.

En esas fechas, la decadencia física de Yrigoyen y las consecuencias de las crisis de 1929 provocaron un alarmante estado de inquietud en el país. En junio, Cortesi trasmitió ante la Secretaría de Estado que parecía llegado el momento de pasar a la acción. La debilidad del gobierno, la disputas en el seno de la Unión Cívica Radical, la parálisis de las organizaciones católicas que se le habían manifestado afines previamente, y el malestar social provocado por la crisis institucional y económica, eran juzgadas por el nuncio como momento adecuado para poner en el centro de la escena las nuevas fuerzas católicas, organizadas ahora por la mano

27 «Con todos los altos personajes con quienes he conversado he encontrado la mejor impresión para nuestro país... Debo referirme especialmente al Cardenal Cerretti... el cardenal Lépicier, y los superiores de Franciscanos y Jesuitas, especialmente este último... La idea tiene atmósfera propicia... No dudo que el Gobierno cooperaría en este sentido y su mejor contribución se traduciría influyendo en el aumento de las diócesis que es tan necesario». Tomás R. Cullen a Cortesi (30/04/1930). ASV, ANA, Caja 121, Fascículo 592: 86-88.

${ }_{28}$ "Creo que el Duce le ha hecho un innegable beneficio a este país terminando con el sectarismo masónico... despertando un sentimiento de disciplina y respeto a la autoridad... Nos ha llamado la atención el gran renacimiento religioso que se observa en todas partes y el profundo respeto para los sacerdotes y las ceremonias de culto». Tomás $\mathrm{R}$. Cullen a Cortesi (10/06/1930). ASV, ANA, Caja 121, Fascículo 592: 94-99.

${ }_{29}$ Conclusiones del Congreso Eucarístico de Cartago. Memoria aportada por Tomás Cullen (10/05/1930). ARSI, Nuova Compagnia, Provincia Argentino-Chilensis. Epistolae: legajo 1011; Praepos. Provinc; documento 21. 
maestra de la jerarquía pontificia. Solo había que aguardar al momento oportuno $^{30}$.

\section{Con la ayuda de Dios... y del ejército. Cortesi y el régimen del General Uriburu}

El 6 de septiembre de 1930 el nuncio trasmitió de manera urgente los acontecimientos relacionados con el derrocamiento del presidente Yrigoyen y el golpe militar del General Uriburu. La documentación de la Secretaría de Estado permite seguir los telegramas cursados en aquellas horas $^{31}$. El 22 de septiembre Cortesi presentó ante la Secretaría de Estado el primer informe extenso sobre la situación política generada tras el golpe. Sus palabras no escatimaban críticas para el presidente derrocado y justificaban el carácter preventivo de la intervención armada frente a la hipótesis de una expansión de la dinámica revolucionaria. Apenas dos semanas transcurridas desde el golpe, el nuncio exhibía sin reparos el exaltado discurso de la propaganda patriótica que calificaba los hechos como feliz hito trascendental en la historia de la República ${ }^{32}$. También expresaba su satisfacción por la conformación del nuevo gobierno, caracterizado no sólo por la ocupación de cargos relevantes por prominentes católicos, sino por la nueva liturgia política desplegada desde el poder, que auguraba una República mucho más afín a los intereses eclesiales. El golpe o, en palabras del nuncio, el movimiento revolucionario, parecía para mu-

30 «El momento parece muy propicio. La confusión en el campo de la vida pública, la desorientación política general, la indisciplina inmersa en las aulas universitarias e incluso entre las escuelas secundarias del Estado, las graves amenazas de atentados contra el orden civil cristiano por parte de los comunistas socios de la Internacional de Moscú, que han introducido en la capital un buen número de propagandistas revolucionarios: inducen a muchos a reflexionar y a buscar la luz, la guía y la salvación donde sólo pueden encontrarla... Por tales motivos, me permito solicitar las instrucciones que la Santa Sede crea oportuno comunicar a los obispos». Cortesi a Secretaría de Estado (16/06/1930). AAEESS, Argentina, Fascículo 66: 52-53.

31 AAEESS, Argentina, Fascículo 70: 3-9.

32 «El golpe no fue una sorpresa. Crecía desde hace dos años el descontento... El recurso a la violencia parecía el único medio posible para restablecer el orden político y administrativo y salvar al país del caos que se acercaba a gran velocidad... Peligro de que elementos comunistas, unidos a los socialistas rojos, pudiesen, en la confusión general, intentar un golpe audaz contra el gobierno y el orden público». Cortesi a Secretaría de Estado (22/09/1930). AAEESS, Argentina, Fascículo 70: 10-15. 
chos obra de la Providencia, e inauguraba un nuevo tiempo para la Argentina ${ }^{33}$.

Ya en esas tempranas fechas Cortesi presentaba ante Pacelli la estrategia política que debería aplicarse en los próximos meses para avanzar en la construcción de un nuevo Estado, mientras se aplacaba a los enemigos, y se fortalecía a los aliados. Un plan estratégico que se realizaría casi milimétricamente en los próximos años. El nuncio consideraba el cambio de régimen una excelente oportunidad para poner en marcha todos aquellos proyectos con los que Pío XI había encontrado demasiadas dificultades en la Argentina de los años previos. Un gobierno afín a los postulados conservadores y colaborador estrecho de las instituciones eclesiásticas serviría de privilegiada plataforma para ejecutar las tareas pendientes, incluyendo una futura reforma constitucional en la que los intereses de la Iglesia se verían favorecidos ${ }^{34}$.

Las ventajosas condiciones que supuso el nuevo gobierno para la Iglesia pudieron constatarse en pocas semanas con la aprobación definitiva de los Estatutos de la Acción Católica Argentina y la disolución de la antigua $U P C A^{35}$. Tras la carta enviada por Monseñor Tardini con algunas su-

33 «La historia de la República no registra un hecho revolucionario como este, que haya obtenido el unánime y pleno consenso de la ciudadanía. Los periódicos comparan la jornada del 6 de septiembre de 1930 con la de la emancipación política del 25 de mayo de 1810... Incontenible afirmación de voluntad nacional... Particular satisfacción causó el nombramiento de los hombres llamados al gobierno provisional... la mayor parte, católicos practicantes... Llama la atención que en un momento de profunda crisis, la Nación ha querido buscar su salvación en la más sana tradición del país, representada por personas de fe católica...Persuasión general de que el movimiento revolucionario ha salvado al país de la ruina y que se lo considera como providencial entre las personas con buen sentido». Ídem.

34 «La idea de formar un partido nacional de tendencia conservadora, con carta orgánica y programa de principios bien definidos... no presenta probabilidad de buen éxito. Parece más razonable hacer imponer la idea de una alianza o coordinación de los diversos partidos en el campo electoral... Todos... menos los radicales, antipersonalistas, los comunistas y los socialistas rojos que intentan cada uno tomar parte por sí... Es incierta la actitud que tomará el Partido Radical personalista que, expulsado de todas las instituciones oficiales, se encuentra actualmente dividido... Estamos en una hora solemne y grave... La caída del Presidente Yrigoyen no afecta a los intereses de la Iglesia... Podrá señalar el principio de una saludable restauración... Ocasión oportuna para resolver el problema de las relaciones entre la Iglesia y el Estado, pendiente en la Constitución». Ídem.

35 «Se aprecia, es cierto, una cierta resistencia entre grupos que sin formación alguna y sin vocación de verdadero apostolado han figurado hasta ahora en la llamada UPCA... Convendrá contar así con mucha paciencia y sutileza, pero estos tales deberán ser necesariamente excluidos de los puestos de dirección». Cortesi a Secretaría de Estado (10/10/1930). AAESS. Argentina, Fascículo 66: 55-56. 
gerencias para los nuevos Estatutos, aceptadas las modificaciones, sólo quedaba pendiente la delicada cuestión de la gestión de los fondos generados por la Gran Colecta Nacional de 1919. Unos seis millones de pesos argentinos se habían invertido en bienes inmuebles. La celebración de una Semana Social para el clero dirigida por dos sacerdotes recién llegados de Roma y destinados a regir la Iglesia argentina en las próximas décadas, como Antonio Caggiano y Froilán Ferreira Reinafe; y la organización de una Semana de Acción Católica presidida por Luigi Civardi servirían como prólogo de la constitución definitiva de la organización, inserta en los moldes romanos. El 4 de diciembre de 1930 el papa Pío XI envío una carta al episcopado argentino que daba carta de naturaleza definitiva a la Acción Católica Argentina. El 5 de abril de 1931 el episcopado argentino publicó una carta pastoral colectiva por la que se hacían públicos los estatutos de la organización. Superando el discurso teórico que la jerarquía episcopal había exhibido en los años previos, la misiva manifestaba de manera diáfana la asunción de un lenguaje bélico que, inspirado por la cruzada contra la serpiente del materialismo, presentaba a la institución eclesial como garantía y salvaguarda de los sagrados deberes de un Estado católico ${ }^{36}$.

Sólo unas semanas antes, mientras se anunciaba la convocatoria de las elecciones municipales, Juan Agustín Boneo había publicado una pastoral en su diócesis de Santa Fe que acabó convirtiéndose en arma arrojadiza para la batalla política, por sus enfrentamientos con el gobernador de la provincia, el católico Doctor Molinas, y con el candidato del Partido Demócrata Progresista, Lisandro de La Torre, que contaban inicialmente con el apoyo del gobierno de Uriburu ${ }^{37}$. El informe final que el nuncio presentó ante la Secretaría de Estado elogiaba la actitud del obispo y su clamorosa batalla ante sus adversarios. Sus planteamientos habían sido asumidos como tales por el frente con-

${ }^{36}$ Carta Pastoral Colectiva del episcopado Argentino, 5 de abril de 1931. Firmada por el arzobispo de Buenos Aires, los obispos de las diócesis de Santa Fe, La Plata, Corrientes, Cuyo, Salta, Córdoba, Paraná, Santiago del Estero, Tucumán y el vicario capitular de Catamarca.

37 «Sorprende la fortaleza de ánimo y lucidez del venerable prelado que a sus 85 años parece rejuvenecer cada vez que se trata de defender los derechos de la religión y de la iglesia católica. Admirable ejemplo en un país en que los actos de fortaleza pastoral son excepcionalmente raros». Cortesi a Secretaría de Estado (30/03/1931). AAEESS, Argentina, fascículo 70 . 
servador que convertía la defensa del catolicismo en uno de sus pilares programáticos ${ }^{38}$.

La publicación en abril de 1931 de un extenso opúsculo firmado por Gustavo J. Franceschi, con el significativo título ;Son los obispos funcionarios del Estado ${ }^{39}$, arropó los primeros pasos de la Acción Católica Argentina. La Iglesia que había obtenido los favores del nuevo régimen, reivindicaba su espacio de actuación autónomo respecto al Estado. A ojos del nuncio, todo parecía marchar por el camino de la virtud. Sin embargo, la Secretaría de Estado del Vaticano contaba también con la opinión de otros dirigentes eclesiásticos, profundamente alarmados por la connivencia establecida entre la jerarquía y las clases privilegiadas que habían tomado el poder excluyendo a los movimientos populares. A finales de mayo de 1931, la estancia de De Andrea en Europa culminó con la entrega de un extenso informe confidencial ante la curia sobre la peligrosa situación política de la Iglesia en Argentina ${ }^{40}$. Su interpretación sobre el golpe de septiembre resultaba radicalmente opuesta a la que meses antes había sido presentada por el nuncio. A su juicio, la imagen trasmitida por Cortesi resultaba engañosa; el verdadero panorama eclesial era desolador y la situación política arriesgada. Las perspectivas de futuro para la Iglesia argentina resultaban alarmantes. De Andrea, alejado de los cánticos laudatorios del nuncio, se mostraba extraordina-

38 «Ha servido a los más vitales intereses del a religión, no menos que los de la nación... Se ha dicho que en la debatida cuestión, el obispo de Santa Fe ha triunfado en toda línea, y así es verdaderamente». Cortesi a Secretaría de Estado (28/04/1931). AAEESS, Argentina, fascículo 70, documento 31 .

${ }^{39}$ Gustavo J. Franceschi ¿Son los obispos funcionarios del Estado?, publicación de la Junta Nacional de AC (5/04/1931). ASV, ANA, Caja 113: 166-189.

40 «La opinión pública fue engañada, creyendo que el nuevo gobierno, una vez alejado el ex presidente, cumpliría con su misión de convocar al pueblo para nuevas elecciones, y para restaurar inmediatamente la vida normal de la constitución... El actual gobierno está compuesto de hombres conservadores, pertenecientes a un círculo restringido de capitalistas y que ciertamente puede ser fácilmente considerado como un gobierno destinado a agriar la lucha de clases... Podrá de un momento a otro, darse una revolución mucho más terrible que la anterior, porque al menos una parte del ejército... contaría con el favor de los partidos de la izquierda... Los radicales que no tienen principios religiosos, pero que por voluntad del ex-presidente los respetaban, y los socialistas, serán los árbitros de la reforma constitucional... Los daños a la Iglesia son incalculables, si se añade además que el ejemplo de Argentina es el que da el tono a toda la América del Sur, y pronto se vería imitada por todas las otras repúblicas». Memoria de Mons. De Andrea entregada en la Secretaría de Estado durante la reunión mantenida con Giuseppe Pizzardo y Eugenio Pacelli (30/05/1931). AAEESS, Argentina, Fascículo 66: 6-24. 
riamente escéptico; ni siquiera, la reciente constitución de la Acción Católica ofrecía para el antiguo dirigente de la UPCA visos de esperanza. En su opinión, solo una autoridad jerárquica con la fuerza y el prestigio suficiente, podría impulsar las reformas necesarias; una autoridad para la que el mismo obispo de Temnos, postergado en 1923, parecía volver a postularse.

El 26 de diciembre de 1931 Cortesi informó exultante sobre las elecciones celebradas el 8 de noviembre y la conformación de un futuro gobierno presidido por el General Agustín Pedro Justo, el antiguo ministro de la guerra que en 1923 había resultado tan decisivo para la aprobación del servicio eclesiástico castrense. En su opinión, los resultados no sólo habían sido extraordinariamente positivos para los partidos conservadores, sino que habían puesto en valor el peso decisivo de los católicos en la confrontación electoral y en el gobierno ${ }^{41}$. Las elecciones consumaban la exitosa alianza establecida entre la jerarquía eclesiástica y el ejército en la nueva república de las virtudes católicas. Los elogios al nuevo presidente no dejaban dudas del feliz acontecimiento. Sin embargo, el nuncio examinaba también las posibles dificultades para la futura labor de gobierno. La reforma constitucional se antojaba por ahora demasiado arriesgada y era necesario dar tiempo al tiempo y ver como evolucionaban los acontecimientos, contando con la movilización emergente de los católicos, el disciplinado ejército de la Acción Católica a las órdenes de la jerarquía y las próximas conmemoraciones festivas que fortalecerían las bases de una nación católica. Convenía tener muy en cuenta las posibles amenazas para los proyectos apuntados. El triunfo electoral de los socialistas en la capital y las actividades de grupos comunistas justificaban las medidas represivas aplicadas por el gobierno.

Significativamente, el informe del mismo acontecimiento emitido por De Andrea exhibía de nuevo poderosas divergencias en cuanto a la interpretación del proceso político. El dirigente de la defenestrada UPCA no escatimaba críticas para el nuevo gobierno y alertaba sobre su posible

41 «En raras ocasiones en la historia de la Argentina las elecciones populares tuvieron tanta importancia... El triunfo de los partidos de la derecha en el nombre del General Justo parece a muchos, y lo es, verdaderamente providencial... No hay quien no aprecie en cuanto han contribuido a este feliz resultado el voto de los católicos... Se puede ciertamente afirmar que la autoridad de la Iglesia no sólo ha salido triunfante de los injustos ataques de sus detractores, sino que ha crecido en prestigio». Cortesi a Secretaría de Estado (26/12/1931). AAEESS, Argentina, Fascículo 70: documento 32. 
incitación a una convocatoria revolucionaria ${ }^{42}$; pero los requerimientos efectuados por De Andrea ante Pacelli no fueron correspondidos. Cortesi siguió contando con la confianza de Pío XI. Incluso Gustavo Franceschi, antiguo aliado de De Andrea, se inclinó a seguir los pasos del nuncio, mientras mostraba su preocupación por frenar el avance de los postulados fascistas $^{43}$. Las denuncias llegadas hasta Roma contra su figura fueron retiradas por la intervención de Cortesi ${ }^{44}$, y su éxito en las labores de propaganda lo convertirían pronto en director de la revista Criterio, referencia de prestigio para las élites intelectuales católicas.

\section{Apoteosis vaticana. Cortesi y el gobierno del General Justo}

En febrero de 1932 la conformación del nuevo gabinete confirmó la concordancia entre las diversas fuerzas conservadoras. El prestigioso jurista Carlos Saavedra Lamas se hizo cargo del Ministerio de Relaciones Exteriores y Culto, encargado de gestionar las cuestiones pendientes relacionadas con el patronato. Aprobados los Estatutos de la Acción Católica, resultaba imprescindible otorgar un nuevo liderazgo a una Iglesia metropolitana que, presidida por Bottaro, cada vez más débil y enfermo, seguía mostrando graves síntomas de división. El favorito de Cortesi para asumir el cargo era el obispo auxiliar Santiago Luis Copello, pero el binomio Copello-Cortesi se había convertido por entonces en objeto de crítica de una

42 «El triunfo se debe a la abstención del radicalismo y al apoyo oficial... ¿Cómo podrá el General Justo constituir su gobierno?.... ¿No estaremos ante la vigilia de otros sucesos de violencia peores que los del pasado?... Se acusa públicamente a la Iglesia de entrometerse en política y ya se preparan y esperan para hacérselo pagar». Informe de Mons. De Andrea (2/01/1932), enviado por Vasallo, nuncio en Munich, a Eugenio Pacelli (30/01/1932). AAEESS, Argentina, Fascículo 70: 42-44.

43 «La tiranía fascista está ejerciendo una deprimente influencia sobre el otrora libre espíritu italiano». Gustavo J. Franceschi: «La persecución fascista», El Pueblo (10/07/1931). AAEESS, Argentina, sobre las denuncias presentadas contra G.J. Franceschi, Fascículo 73, páginas 14 a 15.

44 «Reconocidos sus errores, dicho Monseñor se mantiene desde hace años alejado de los círculos de Monseñor Andrea y durante mi misión su conducta ha sido de absoluta adhesión a las directivas del Santo Padre que ha conciliado con la estima del obispo, del clero y de los católicos, por lo que creo que tiene méritos y honores». Cortesi a Secretaría de Estado ante denuncias presentadas contra Franceschi (8/03/1933). AAEESS, Argentina, Fascículo 73: 16. 
parte del clero que alcanzó con sus denuncias las instancias vaticanas ${ }^{45}$; un malestar que parecía tener peligrosas implicaciones políticas.

Ante las demandas suscitadas por la Secretaría de Estado, el nuncio defendía a su favorito y restaba importancia a unas críticas airadas que no se correspondían con la situación general del clero, y que sólo se entendían por la resistencia de algunos clérigos a someterse a las necesarias medidas disciplinarias ${ }^{46}$. El catálogo de beneficiados por la política diseñada por la nunciatura incluía la creciente influencia de los jesuitas, que pronto se hicieron con la exclusiva de la organización de los retiros espirituales obligatorios para todos los sacerdotes diocesanos ${ }^{47}$; pero también a algunas familias de la pujante burguesía, que atesoraron en esos años condecoraciones y títulos de nobleza pontificia, tras otorgar importantes donaciones para la construcción de templos y obras eclesiásticas ${ }^{48}$.

45 «El señor Nuncio... rodeado de aduladores permanentemente y especialmente comprometido con algunas señoras ricas (verdadera plaga del clero) y esposas de politicos... quiere a cualquier precio como arzobispo a Mons. Santiago Copello. Es este un error grandísimo que será causa de dolorosas consecuencias... Su espíritu es completamente contrario al espíritu de un buen pastor... Se muestra hasta lo increíble, despótico, sin piedad y sin razón. Ha comenzado a maltratar al clero en todas sus formas, secundado en esto por su vicario general Antonio Roca... No puede imaginar Santidad los abusos que estos dos eclesiásticos han cometido... Mons. Copello figura como el apóstol encargado de construir iglesias y casas parroquiales! ¿Y el dinero?, ¿dónde va todo el dinero recaudado para estas obras? Pues al ingeniero Mozza intimo amigo de Mons. Copello!!!». Giulio Aiuti, sacerdote italiano en Argentina, al papa Pío XI (27/08/1932). AAEESS, Argentina, Fascículo 86: 8-10.

46 «Las denuncias... no tienen ningún fundamento y sin duda provienen de sacerdotes tendientes a la indisciplina, si no rebeldes a la autoridad eclesiástica... Le es contrario un grupo de pocos sacerdotes afectados por una especie de fanatismo, que se obstinan en creer como único candidato llamado a gobernar la archidiócesis a Mons. De Andrea». Cortesi a Secretaría de Estado sobre conflictos del clero con Mons. Copello (25/09/1932). AA.EE.SS. Argentina, Fascículo 86: 12-13.

47 Estadística del número de jesuitas en abril de 1935. Total: 491; 187 en Buenos Aires; 124 en Córdoba; 108 en Santiago de Chile... En Catalogus Provinciae Argentino-Chilensis. S.J., 1935.

${ }^{48}$ La condesa Adelia María Hilarios, viuda de Olmos, obtuvo el título de marquesa tras ceder su palacio como residencia del comité ejecutivo y del legado pontificio durante el Congreso Eucarístico. En su testamento donó un millón de pesos argentinos para el Ateneo de la Juventud; María Unzué, viuda de Ángel T. de Alvear, afrontó la construcción del templo de Santa Rosa de Lima en Buenos Aires donando 2 millones y medio de pesos. Informe del nuncio de Argentina a la Secretaría de Estado del Vaticano sobre solicitud de condecoraciones pontificias (20/11/1934). ASV, ANA, Caja 121, Fascículo 592: 218-228. 
En octubre de 1932 el Vaticano - siguiendo los dictados de Cortesi- designó a Luis Copello nuevo metropolitano de Buenos Aires; en diciembre de ese mismo año el nuevo arzobispo tomó posesión definitiva de la archidiócesis. Mientras tanto, Antonio Caggiano, tras haber ejercido previamente como garante del sometimiento a la disciplina jerárquica en la Acción Católica, se hacía cargo del vicariato castrense, y Gustavo J. Franceschi, absuelto definitivamente por el nuncio de sus antiguas convivencias con De Andrea, se convertía en director del semanario Criterio. Las piezas comenzaban a encajar como en un mecano. Con un gobierno proclive a sus políticas, la puesta en marcha de la Acción Católica y la alianza establecida entre la jerarquía eclesiástica y poderosas familias; la soñada erección de nuevas diócesis y la celebración del futuro Congreso Eucarístico Internacional se convertirían en excelentes oportunidades para exhibir la tesis nacional-católica.

El idilio vivido entre la jerarquía eclesiástica y el gobierno de Justo generó frutos valiosos y abundantes. El primero de ellos y el de mayor trascendencia para el futuro sería el de la erección de nuevas diócesis que transformarían de manera radical, no sólo el mapa territorial de la Iglesia argentina, sino el equilibrio de poder entre el episcopado, que desde esa fecha se puso a plena disposición de los dictados de Roma. El 20 de abril de 1934 la bula pontificia Nobilis Argentinae Nationis (Ley 116, Decreto 45984/1934) creaba diez nuevas diócesis que venían a sumarse a las once existentes hasta esa fecha.

Si la difusión de la nueva estructura eclesiástica por todo el territorio nacional propició un recambio generacional del clero diocesano mucho más afín a las directrices romanas, la celebración del próximo Congreso Eucarístico Internacional se presentó como un nuevo peldaño en la reconquista católica de las masas. Los informes del nuncio ante la Secretaría de Estado insistían en la plena colaboración de todas las instancias gubernamentales para el éxito de la feliz iniciativa ${ }^{49}$; pero el arrollador triunfo del Congreso sólo se explica por el proceso previo de organización de congresos locales, diocesanos, regionales y nacionales que sirvieron de caldo de

49 «Diligentísima obra se ha realizado para garantizar el orden y la seguridad... misión al encargo de la policía de la capital, apoyada y secundada por las tropas del ejército regular y de miles de jóvenes católicos entrenados para ello... El Gobierno con su apoyo oficial al Congreso está decidido a prevenir y reprimir la campaña sectaria que de hecho no tenido gran éxito». Cortesi a Secretaría de Estado (4/09/1934), ASV, ANA, Caja 121, Fascículo 592: 45-48. 
cultivo para el magno acontecimiento. El intenso trabajo desarrollado en los años precedentes por parroquias y congregaciones religiosas exhibiría sus resultados en las avenidas de Buenos Aires, ocupadas por millares de católicos llegados de todos los rincones del país. Un movimiento eucarístico que alcanzó también el espacio escolar y universitario en un país que se había caracterizado hasta esas fechas por la defensa de una educación laica, el mejor testimonio del proceso de conversión nacional -en palabras del nuncio - . Del mismo modo, la relación entre el clero y el ejército se hizo cada vez más estrecha, hasta convertir los principios católicos en fundamento del espíritu castrense.

Cuando todo parecía indicar que el cardenal arzobispo de Palermo, Luigi Levitrano, ejercería como legado pontificio en Buenos Aires, el 25 de julio, Alfredo Ottaviani, comunicó a Cortesi que, finalmente, sopesadas todas las materias en juego, el mismísimo Secretario de Estado del Vaticano presidiría el Congreso. El júbilo que tal noticia provocó entre el clero, los católicos y las instancias gubernamentales de la Argentina, incrementó los esfuerzos finales para el éxito del ansiado proyecto. El 14 de octubre la jornada de clausura finalizó con una magna procesión en la que Pacelli fue agasajado con un triunfal baño de masas. Para facilitar la comunicación entre el cardenal y el público concentrado en la Avenida Alvear se diseñó incluso el primer «legadomóvil» de la historia ${ }^{50}$. La invocación a la tradición se conjugaba así con todos los medios posibles aportados por la modernidad y la primera emisión radiofónica transoceánica de las palabras del pontífice fue solo otra de las muestras de esa apoteósica simbiosis ${ }^{51}$.

50 «Se prevé una concentración enorme de espectadores, reunidos en colas de una longitud insólita... Si el Legado, portando el sagrado ostensorio, caminase a pie, y en plano de la Avenida Alvear estos peregrinos, venidos de lejos a millares para ver la santa Ostia triunfante, no la verían ... Ha sido ideado por el ingeniero Giorgio Mayol un dispositivo especial, estudiado a propósito para evitar todos los inconvenientes y ofrecer todas las garantías exigibles... Se trata de una plataforma móvil... una bella y rica capilla portátil». Cortesi a Secretaría de Estado (4/10/1934). ASV, ANA, Caja 121, Fascículo 592: 67-73.

51 «Una de las grandes maravillas ha sido la Radio... la bendición del Santo Padre se oyó con tal claridad y potencia de voz, como si Su Santidad hubiera estado hablando fuerte con su acento natural, desde la habitación contigua a la mía». Augusto Macnab, canónigo de Buenos Aires, a G. Pizzardo (5/12/1934). AAEESS, Argentina, Fascículo 82: 32-33. 


\section{De Buenos Aires a América... y a España}

El éxito del Congreso consagró la capacidad de movilización de las masas católicas dirigidas por la jerarquía eclesiástica y amparadas por un Estado proclive a sus principios e intereses ${ }^{52}$. La Iglesia argentina mostraba su plena satisfacción por la colaboración con el régimen del General Justo. En sus informes privados a Pacelli los elogios del nuncio a la obra desarrollada por el presidente no dejan lugar a dudas ${ }^{53}$. Las exitosas políticas impulsadas desde la nunciatura de Buenos Aires habían tenido además su eco en los países vecinos; muy especialmente en Uruguay donde - como informaba el arzobispo de Montevideo - la dictadura impuesta por José Luis Gabriel Terra había dado un significativo vuelco respecto a los intereses de los católicos en ese país ${ }^{54}$.

En agosto de 1935 Cortesi presentó un informe aleccionador sobre la situación de la Iglesia argentina ${ }^{55}$. Los antiguos dirigentes de la UPCA habían sido enviados al ostracismo o se habían convertido como Franceschi a las nuevas disposiciones marcadas por Roma; el comité archidiocesano de Congresos Eucarísticos proyectaba la conformación de un comité nacional; las obras de construcción de nuevos Seminarios y nuevas casas parroquiales avanzaban notablemente; y la Acción Católica progresaba en

52 «La infinita generosidad del Señor ha dado el ciento por uno, haciendo que este Congreso, el primero que se celebra en el continente sudamericano, se haya convertido en uno de los más solemnes». Cortesi a Eugenio Pacelli (16/11/1934). ASV, ANA, Caja 121, Fascículo 592: 80-82.

53 «Quizás ningún presidente argentino haya sido más sinceramente devoto de la Iglesia, respeto a sus inviolables derechos... Contribuyó a renovar la faz de la nación en su fe católica, después de un largo periodo de progresiva laicización estatal y de la apostasía de los gobernantes». Cortesi a Pacelli (20/11/1934). ASV, ANA, Caja 113, Fascículo 592: 218-228.

54 «El éxito sobrepasó los cálculos y las previsiones más optimistas... Nuestra república de Uruguay, ha sido después de la Argentina la más beneficiada por el Congreso... Nunca se había visto cosa igual en este país... Principio de unas relaciones más cordiales entre la Iglesia y el Estado... El gobierno actual nos favorece... En la nueva Constitución, esperamos recuperar terreno, en muchas cosas. Bajo los auspicios del congreso hemos fundado en el Uruguay la AC». Juan Francisco Aragone, arzobispo de Montevideo, a Secretaría de Estado (4/11/1934). AAEESS, Argentina, Fascículo 82: 28-30.

55 «Signos evidentes de la amorosa Providencia divina: el aumento de la jerarquía realizada hasta la fecha con el nombramiento de 19 obispos diocesanos, todos jóvenes, celosos y activos, la organización de la AC felizmente completa y a al mismo tiempo este movimiento renovador del Congreso Eucarístico». Cortesi a Secretaría de Estado sobre «Normas generales para América Latina» (17/08/1935). AAEESS, Argentina, Fascículo 86: 66-77. 
todas sus ramas. Sin embargo, el nuncio seguía mostrándose crítico con una parte del clero argentino, todavía indiferente a las mieles que podrían generar su mayor implicación en la organización. También criticaba por vez primera a Luis Copello, a quien consideraba máximo responsable del escaso arraigo de la Acción Católica en la capital. Cortesi advertía sobre los riesgos de un anunciado proyecto de ley de divorcio que el arzobispo de Buenos Aires manifestaba haber conjurado ${ }^{56}$; y revelaba ante la Secretaría de Estado el impacto creciente que los postulados nacionalistas estaban adquiriendo entre jóvenes de las organizaciones católicas ${ }^{57}$; una influencia que resultaría decisiva en el futuro ${ }^{58}$.

Como era de esperar, no todos los católicos mostraban su satisfacción por ese estado de relaciones entre la Iglesia y el régimen. Un clero que en años anteriores había contado con mayor autonomía en su acción, se veía ahora sometido a mayores controles; constatación inequívoca de la implantación progresiva de los principios de disciplina y jerarquía tan anhelados por la curia vaticana ${ }^{59}$. El 11 de octubre de 1935 el arzobispo

56 «Habiendo sabido hace más de un año que en la comisión oficial que preparaba la reforma del código civil para presentarlo a la aprobación de las cámaras, tenía mayoría la opinión de incluir el divorcio, comencé a trabajar en contra, comprometiendo también al Sr. Presidente y me es grato consignar que ahora tiene mayoría la parte adversa al divorcio». Luis Copello, arzobispo de Buenos Aires, a Secretaría de Estado (17/05/1935). AAEESS, Argentina, Fascículo 82: 35-37.

57 «Al iniciarse la revolución del 6 de septiembre de 1930, se formaron en el país grupos católicos de carácter nacionalista, integrados por hombres de tendencias doctrinarias diversas, ausentes por tanto de la homogeneidad que convenía para exaltar los valores tradicionales con el lema Dios, Religión y Patria, para implantar, en lugar de los decadentes instituciones demo-liberales, una nueva forma de gobierno sobre la base del corporativismo... Tal movimiento se ha convertido ahora en más complejo y delicado, también porque los militares de altísima graduación no parecen ser ajenos a ello. Algunos dirigentes nacionalistas afirman sin ambages el propósito de recurrir a la violencia para apoderase del gobierno». Cortesi a Secretaría de Estado sobre «Normas generales para América Latina» (17/08/1935). AAEESS, Argentina, Fascículo 86: 66-77.

58 DEVOTO, 2002.

59 «Innumerables abusos... Han producido mala impresión las visitas insistentes al nuncio por parte de los Jesuitas... El clero regular... vive en un estado, digámoslo así, de privilegio y de libertad, porque no puede ser objeto de abuso por parte de la autoridad eclesiástica, al tener sus cardenales protectores en Roma que le salvan de cualquier atentado de la autoridad eclesiástica argentina... Parroquias donde los fieles prefieren y aprecian al sacerdote italiano, frente al español y especialmente frente al nacido en la Argentina». Giulio Aiuti, sacerdote del Instituto para la emigración italiana, a Secretaría de Estado, sobre el estado del clero italiano en la República Argentina (abril de 1935). AAEESS, Argentina, Fascículo 86: 15-62. 
Copello envió a la Secretaría de Estado un informe extraordinariamente positivo sobre la situación del clero y de la Acción Católica Argentina.

Acción Católica Argentina (número de centros y de militantes) ${ }^{60}$

\begin{tabular}{lcccc}
\hline \multicolumn{1}{c}{ Centros / Socios } & Junio 1932 & Junio 1933 & Mayo 1934 & Mayo 1935 \\
\hline Total & 327 & $841 / 20.206$ & $1.204 / 25.153$ & $1.308 / 27.405$ \\
\hline Hombres & 76 & $184 / 4.048$ & $278 / 5.086$ & $290 / 5.501$ \\
\hline Damas & 81 & $199 / 5.177$ & $294 / 6.602$ & $326 / 7.762$ \\
\hline Juventud Masculina & 55 & $197 / 3.831$ & $259 / 4.853$ & $288 / 5.484$ \\
\hline Juventud Femenina & 115 & $261 / 7.150$ & $373 / 8.612$ & $404 / 8.658$ \\
\hline
\end{tabular}

Al día siguiente, los obispos de todas las diócesis y las huestes de la Acción Católica Argentina presentes en el acto de conmemoración del primer aniversario del Congreso Eucarístico testificaron el triunfo de la Iglesia romana y la exaltación del discurso nacional-católico ${ }^{61}$. El 16 de diciembre de 1935 Santiago Luis Copello fue proclamado cardenal por Pío XI; era el primero en la historia de Argentina y su birreta cardenalicia le otorgaría un protagonismo que eclipsaría la figura del mismísimo nuncio, que jamás ostentaría tal honor.

El proyecto de romanización de la Iglesia argentina y su sometimiento a los dictados de Pío XI parecía haber contado con los designios de la providencia, pero la gestión de la nunciatura en los años previos había tenido mucho que ver con ello. Mientras se encargaba de gestionar las últimas

${ }^{60}$ Estadística del informe presentado por el arzobispo de Buenos Aires a la Secretaría de Estado sobre la situación de la Iglesia en Argentina (11/10/1935). AAEESS, Argentina, Fascículo 86: 77-99.

61 «La cruz de Palermo que se alzará a la entrada del puerto de Buenos Aires como constante e inequívoca profesión de fe de esta noble nación cara al mundo entero; un severo aviso para cuantos sembradores de errores y provocadores de desórdenes osaron apoderarse de la ciudad, ahora sede del más grande triunfo del Dios de la verdad y la caridad, y en definitiva una solemne manifestación de cordial e infinita romanidad de toda la República Argentina». Informe del secretario de la nunciatura a Secretaría de Estado sobre conmemoración del aniversario del Congreso Eucarístico (23/10/1935). ASV, ANA, Caja 121, Fascículo 592: 371-377. 
condecoraciones pontificias para militares y notables colaboradores en la obra eclesiástica, tras quince años ocupándose del gobierno de las Iglesias de Latinoamérica, Filippo Cortesi pensaba ya en su regreso a la vieja Europa. Los rumores insistentes sobre su próxima consagración como cardenal se vieron acallados el 4 de junio de 1936, cuando se hizo pública su designación como nuevo nuncio en Madrid. El triunfo electoral del Frente Popular había excitado entre los católicos españoles los temores y los cánticos que convocaban a una cruzada, espiritual o armada, si resultaba necesario; pero el golpe militar de julio de 1936 y el inicio de la guerra civil impedirían que el nuevo nuncio llegase a su destino.

Siguiendo las tesis expuestas por Emilio Gentile, Federico Finchelstein ha defendido que la espiral de acontecimientos atravesados por la República Argentina desde los años veinte guarda estrecha relación con la emergencia de un fascismo transnacional ${ }^{62}$. Las políticas eclesiales se vieron influidas por ese contexto, pero deben interpretarse también a través de sus propias dinámicas internas, sujetas a los juegos de intereses y las batallas establecidas entre las diversas tendencias eclesiales. Si el pontificado de Benedicto XV se caracterizó por una diplomacia vaticana más proclive al encuentro con las democracias, que parecían extenderse como modelo triunfante tras los tratados de paz firmados en Versalles; el pontificado de Pío XI respondió al reto de los totalitarismos con un modelo alternativo que, amparado en regímenes autoritarios y corporativos, garantizase la defensa de sus sagrados intereses $^{63}$. El control del clero y de los movimientos seglares emergentes, sujetos cada vez más a las directrices de la curia romana; la alianza con las clases altas y los altos oficiales del ejército, atemorizados ante el eco de las propuestas revolucionarias; y el desarrollo de una Internacional católica movilizada en torno a la figura del pontífice, se observan diáfanamente en el caso argentino. Si el Congreso Eucarístico Internacional sirvió para dar carta de naturaleza a ese nacional-catolicismo a lo argentino, los ecos posteriores de la guerra civil española polarizarían hasta el extremo tales posiciones.

62 GENTILE, 1993 y 2001; FINCHELSTEIN, 2010.

63 MENOZZI, y MORO, 2004; FATTORINI, 2007 y 2013; LEONARDIS, 2014; KERTZER, 2014. 


\section{Siglas de archivos de las fuentes citadas}

ASV. ANA, Archivio Nunziatura Argentina. Arquivio Segreto Vaticano. ASV. ANM, Archivio Nunziatura Madrid. Arquivio Segreto Vaticano. AA.EE.SS., Affari Ecclesiastici Straordinarii. Archivio Segreteria di Stato. ARSI, Archivum Romanum Societatis Iesu, Roma.

\section{Bibliografía citada}

BotTI, Alfonso, Luigi sturzzo e gli amici spagnoli. Carteggi (1924-1951), Rubbetino Editore, 2012.

Devoto, Fernando, Nacionalismo, fascismo y tradicionalismo en la Argentina moderna: una historia, Siglo XXI, Buenos Aires, 2002.

Di EsteFAnO, Roberto y ZANATTA, Loris, Historia de la Iglesia argentina: Desde la Conquista hasta fines del siglo XX, Editorial Sudamericana, Buenos Aires, 2009.

Dolan, Jay P., In search of an American Catholicism. A history of religion and culture in tension, New York, Oxford University Press, New York, 2002.

Domínguez MÉnDEZ, Rubén, «El viaje del Cardenal Benlloch por Iberoamérica en 1923. Los intereses de España e Italia en la correspondencia diplomática del Archivio Segreto Vaticano», Confluenze. Rivista di Studi Iberoamericani, 2013, 5, pp. 218-233.

FAtTorini, Emma, Pio XI, Hitler e Mussolini. La solitudine di un papa, Eiunadi, Torino, 2007; (a cura di). 2013.

FATTORINI, Emma, Diplomazia senza eserciti. La relazioni internazionali della Chiesa di Pio XI, Carocci Editore, Roma, 2013.

FINCHELSTEIN, Federico, Fascismo trasatlántico. Ideología, violencia y sacralidad en Argentina e Italia, 1919-1945, Fondo de Cultura Económica, Buenos Aires, 2010.

GentiLe, Emilio, Il culto del littorio. La sacralizzazione della politica nell'Italia fascista, Roma-Bari, Laterza; Roma-Bari, 1993.

GENTILE, Emilio, Le religioni della politica. Fra democrazie e totalitarismi, Laterza, Roma-Bari, 2001.

GonZÁlez CAlleja, Eduardo, «El Hispanismo autoritario español y el movimiento nacionalista argentino: balance de medio siglo de relaciones políticas e intelectuales (1898-1946)», Hispania, 2007, 67, 226: 599-642.

Kertzer, David I, Il patto col Diavolo. Mussolini e Papa Pío XI. Le relazioni segrete fra il Vaticano e l'Italia fascista, Saggi Rizzoli, Milano, 2014.

LEONARDIS, Massimo de, Fede e diplomazia. Le relazioni internazionali della Santa Sede nell'età contemporanea, Educatt, Milano, 2014. 
Mauro, Diego, «La Mujer Católica y la sociedad de masas en la Argentina de entreguerras. Catolicismo social, consumo e industria cultural en la ciudad de Rosario (1915-1940)», Hispania Sacra, 2014, 66, 133: 235-262.

Mauro, Diego, «Popolari en la Argentina. Luigi Sturzo y el antifascismo católico de entreguerras», Anuario IEHS, 2014-2015, 29-30, pp. 267-287.

Mauro, Diego, «El mutualismo católico en Argentina: el Círculo de Obreros de Rosario en la primera mitad del siglo XX», Historia crítica, 2015, 55, pp. 181-205.

MenOzZI, Daniele y Moro, Renato, Cattolicesimo e totalitarismo. Chiese e culture religiose tra le due guerre mondiali (Italia, Spagna, Francia), Morcelliana, Brescia, 2004.

MirandA, Lida, «Una modernización en clave de cruzada. El diario católico de Buenos Aires en la década de 1920: El Pueblo», Escuela de Historia, 2008,7 .

MirANDA, Lida, «Los orígenes del catolicismo de masas en la Argentina, 19001934, Anuario de Historia de América Latina, 2009, 46, 345-370.

MirANDA, Lida, «¡A Luján! Las comunidades de inmigrantes y el naciente catolicismo de masas, 1910-1934», Revista de Indias, 2010, 250, pp. 809-836.

MirANDA, Lida, «Iglesia católica, sociabilidad y canto gregoriano en Buenos Aires en el primer tercio del siglo XX», Anuario de Historia de la Iglesia, 2012, 21, pp. 401-422.

Miranda, Lida, Monseñor Miguel De Andrea. Obispo y hombre de mundo (18771960), Buenos Aires, Edhasa, Buenos Aires, 2013.

Miranda, Lida y MAURo, Diego (coord.), Catolicismo y sociedad de masas en Argentina: 1900-1950, Protohistoria, Rosario, 2009.

Pollard, John F., The Unknown Pope. Benedict XV (1914-1922) and the Pursuit of Peace, Geoffrey Chapman, London, 1999.

Pollard, John F., Money and the Rise of the Modern Papacy, Cambridge University Press, Cambridge, 2005.

Pollard, John F., The Papacy in the Age of Totalitarianism, 1914-1958, Oxford, Oxford University Press, Oxford, 2014.

ZanatTA, Loris, Del Estado liberal a la nación católica. Iglesia y ejército en los orígenes del peronismo (1930-1944), Universidad Nacional de Quilmes, Buenos Aires, 1996.

ZanatTA, Loris, Perón y el mito de la nación católica. Iglesia y ejército en los orígenes del peronismo (1943-1946), Editorial Sudamericana, Buenos Aires, 1999. 


\section{Datos del autor}

José Ramón Rodríguez Lago, Doctor en Historia Contemporánea por la Universidad de Santiago de Compostela. Profesor del área de Historia Contemporánea en la Universidad de Vigo.

Libros: La Iglesia católica en Galicia, 1910-1936. Entre la revolución de Portugal y la cruzada de España, Andavira, Santiago de Compostela, 2012; Cruzados o herejes. La religión, la Iglesia y los católicos en la Galicia de la guerra civil, Nigratrea, Pontevedra, 2010; La Iglesia en la Galicia del franquismo, Edicios do Castro, Sada-A Coruña, 2004.

Artículos: "Las redes católicas entre España y los Estados Unidos de América», en Historical Links between Spain and North América, Universidad de Alcalá de Henares, 2016; "Centros, periferias y redes eclesiásticas en la España del siglo XX», Historia Actual on line, 35, 2014; "La Iglesia católica y la II República española. Resistencias, progresos y retos pendientes", Hispania Nova, 11, 2013; "La batalla eclesial por Madrid (1923-1936). Los conflictos entre Eijo y Tedeschini», Hispania Sacra, 64, 2012; ¡Salvemos los niños rusos! La Iglesia española y la campaña pontificia en la URSS (1922-1924), Spagna Contemporanea, 42, 2012. 